Огляди літератури, оригінальні дослідження, погляд на проблему, випадок з практики, короткі повідомлення УДК 616.91:578.834.1]-02:616.12-008.46

DOI 10.11603/1811-2471.2021.v.i3.12201

\title{
ОСОБЛИВОСТІ ПЕРЕБІГУ КОРОНАВІРУСНОЇ ХВОРОБИ ПРИ СЕРЦЕВІЙ НЕДОСТАТНОСТІ
} ๑О. О. Самчук', О. С. Капустинська', Є. Я. Скляров²

${ }^{1}$ Комунальне некомерційне підприємство «Клінічна лікарня швидкої медичної допомоги м. Львова» ² Львівський національний медичний університет імені Данила Галицького

РЕзЮМЕ. Висновки попередніх епідемій коронавірусу та грипу, які ґрунтуються на численних дослідженнях, свідчать про те, що вірусні інфекції призводять до декомпенсації раніше існуючої серцевої недостатності (CH) [1]. Коронавірусна хвороба 2019 (COVID-19) - більш агресивна інфекція, при якій ризик таких загострень значно зростає. Останні дані свідчать, що велику частку смертей від COVID-19 можна віднести до серцево-судинних захворювань, включаючи СН [2]. СН пов'язана з майже двократним ризиком госпітальної смертності та лікуванням у відділенні інтенсивної терапії та більш ніж триразовим ризиком штучної вентиляції легень.

Мета роботи - оцінити особливості перебігу COVID-19 у хворих на СН на основі ретроспективного аналізу.

Матеріал і методи. Досліджували клініко-лабораторні особливості перебігу COVID-19 у хворих на хронічну $\mathrm{CH}$, а також ускладнення, результати лікування (виписка/смерть) на основі аналізу медичних карток стаціонарних хворих 389 пацієнтів, які перебували на лікуванні в Комунальному некомерційному підприємстві "Клінічна лікарня швидкої медичної допомоги м. Львова" у січні та лютому 2021 року.

Результати. Хронічну СН виявляли у 46,3 \% пацієнтів із COVID-19. У цих хворих частіше зустрічали задишку (88,2 \% проти 71,4 \% у пацієнтів без хронічної СН, p=0,074), нижчий середній рівень сатурації ( $p=0,027)$. Крім цього, відзначено вищі рівні лейкоцитозу $(p=0,032)$, гіперглікемії $(p<0,0001)$ та креатиніну $(p=0,003)$. У досліджуваній групі пацієнтів частіше зустрічали кардіальні ускладнення, пов'язані з розвитком нестабільної стенокардії (р<0,001), інфаркту міокарда ( $=0,0094)$ та порушенням ритму і провідності $(p<0,001)$. У них була вища частота гострих тромбозів ( $p=0,0181)$, ТЕЛА ( $p<0,001)$ та госпітальної смертності: 27,8 \% проти $10,1 \%(p<0,001)$.

Висновки. Коронавірусна хвороба обтяжує перебіг хронічної серцевої недостатності та проявляється дестабілізацією серцево-судинних проявів хвороби, підвищенням тромбогенного потенціалу, що призводить до високої госпітальної летальності.

КлючовІ СлОВА: COVID-19; серцева недостатність.

Вступ. Висновки попередніх епідемій коронавірусу та грипу, які ґрунтуються на численних дослідженнях, свідчать про те, що вірусні інфекції призводять до декомпенсації раніше існуючої серцевої недостатності (CH) [1]. Коронавірусна хвороба 2019 (COVID-19) - більш агресивна інфекція, при якій ризик таких загострень значно зростає. Останні дані свідчать, що велику частку смертей від COVID-19 можна віднести до серцево-судинних захворювань, включаючи СН [2]. СН пов'язана з майже двократним ризиком госпітальної смертності та лікуванням у відділенні інтенсивної терапії та більш ніж триразовим ризиком штучної вентиляції легень, враховуючи поправку на різноманітні фактори - расу, ожиріння, діабет, попереднє лікування і тяжкість захворювання [3]. Ця супутня патологія у людей старшого віку становить додаткову загрозу для хворих з COVID-19.

На сьогодні розкрито кілька механізмів, відповідальних за цей процес. Зокрема, відомо, що пацієнти з COVID-19 та CH мають подібні фактори ризику, що призводить до збільшення патологічних наслідків. Сюди належать запальна відповідь та пов'язана з нею коагулопатія. Обидва захворювання становлять ризик аритмії. Поліфармація ще більше ускладнює безпеку лікування таких хворих та погіршує прогноз [4]. У більшості пацієнтів СН виникає внаслідок складних взаємодій між вже іс- нуючими станами, пошкодженням серця, активацією ренін-ангіотензинової системи та наслідками системного запалення на серцево-судинну систему $[1,5]$. Подальше вивчення даної проблеми $\epsilon$ надзвичайно актуальним. Правильне розуміння двосторонньої взаємодії між COVID-19 та CH може привести до оптимального лікування і вплинути на прогноз.

Мета - оцінити особливості перебігу COVID-19 у хворих на хронічну $\mathrm{CH}(\mathrm{XCH})$.

Матеріал і методи дослідження. Проведено аналіз медичних карток стаціонарних хворих 389 пацієнтів з діагнозом COVID-19. Усі хворі перебували на лікуванні в Комунальному некомерційному підприємстві "Клінічна лікарня швидкої медичної допомоги м. Львова" у січні та лютому 2021 року. Діагноз COVID-19 був підтверджений шляхом виявлення геному вірусу SARS-CoV-2 у змивах з носо-ротоглотки методом полімеразної ланцюгової реакції із зворотною транскрипцією (ЗТкПЛР), проведеної за допомогою тест-системи HEMA на аналізаторі KING FISHER DO із чутливістю 5 копій на реакцію. Діагноз ХСН верифікували на основі «Рекомендацій з діагностики та лікування хронічної серцевої недостатності (ХCH) Асоціації кардіологів України (2017)».

Оцінювали такі параметри: вік, стать пацієнтів, наявність супутніх захворювань, ускладнень 
Огляди літератури, оригінальні дослідження, погляд на проблему, випадок з практики, короткі повідомлення

та результати лікування (виписування/смерть). Вивчали скарги, анамнез, результати фізичного обстеження та додаткових лабораторно-інструментальних методів обстеження.

Усі пацієнти відповідно до наказу МОЗ України від 11.11.2020 № 2583 «Про внесення змін до протоколу «Надання медичної допомоги для лікування коронавірусної хвороби (COVID-19)» були госпіталізовані за клінічними критеріями хворих 3 підозрою/підтвердженим COVID-19: 1) ЧД <10 або $>30$; 2) сатурацією при вимірюванні пульсоксиметром $\leq 92 \% ; 3$ ) порушенням свідомості (за шкалою AVPU все, крім A); 4) із перебігом захворювання середньої тяжкості та тяжкою супутньою патологією (тяжкий перебіг артеріальної гіпертензії, декомпенсований цукровий діабет, імуносупресивні стани, тяжка хронічна патологія дихальної та серцево-судинної систем, ниркова недостатність) в стадії декомпенсації, тобто відповідали середньотяжкому або тяжкому перебігу COVID-19.

Статистичну обробку даних проводили за допомогою пакета програм Statistica 6.0.

Результати й обговорення. Проаналізовано медичні картки стаціонарних хворих 389 пацієнтів, які перебували на лікуванні в Комунальному некомерційному підприємстві «Клінічна лікарня швидкої медичної допомоги м. Львова» у січні та лютому 2021 року. ХСН була виявлена у 46,3 \% випадках (у 180 хворих). Середній вік пацієнтів дорівнював $(71,3 \pm 9,55)$ років. Частка чоловіків та жінок була практично однаковою - жінок було 49,4%, чоловіків - 50,6 \%. Середній вік жінок дорівнював $(74,11 \pm 8,45)$ років, чоловіків - $(68,55 \pm 9,8)$ років. Переважну частку - 80 \% - складали пацієнти із діагнозом ХCH 1 та 2А стадії, у 20 \% ХСН відповідала 2Б та 3 стадії. У групу порівняння увійшло 209 пацієнтів з COVID-19 без XCH.

Епідеміологічні дослідження чітко продемонстрували провідну роль артеріальної гіпертензії $(\mathrm{AГ})$ та ішемічної хвороби серця (IXC) як популяційних факторів ризику ХCH. У нашому дослідженні поширеність цих нозологій у дослідженій групі пацієнтів була подібною: у 83,9 \% випадках виявляли АГ, у 92,2 \% - IXC, з них 25 \% пацієнтів мали в анамнезі перенесений інфаркт міокарда, у 15 \% діагностували постійну форму фібриляції передсердь. Вагомим фактором ризику ХСН є також цукровий діабет. Його констатували у 26,7 \% хворих з COVID-19 та СH.

Провідним симптомом як дихальної недостатності, яка розвивається при COVID-19 пневмонії, так і СН за лівошлуночковим типом, $є$ задишка. Симптом задишки був присутній у більшості пацієнтів, госпіталізованих із COVID-19 пневмонією. Проте, у пацієнтів із COVID-19 в поєднанні з ХCH він зустрічався частіше $(88,2$ \% проти $71,4 \%$ у пацієнтів без XCH, p=0,074). У цих пацієнтів також виявлено нижчий середній рівень сатурації, порівняно з хворими без ХCH, $\mathrm{p}=0,027$ (табл. 1). Таким чином, у пацієнтів із ХCH частіше зустрічається тяжчий перебіг пнемонії COVID-19.

Таблиця 1. Показники вітальних функцій у хворих на коронавірусну хворобу в поєднанні з ХСН (1 група) та без (2 група)

\begin{tabular}{|l|c|c|c|}
\hline \multicolumn{1}{|c|}{ Показники } & 1 група & 2 група & P \\
\hline $\mathrm{IMT}, \mathrm{\kappa г} / \mathrm{M}^{2}$ & $29,62 \pm 7,31$ & $27,22 \pm 6,84$ & 0,03 \\
\hline $\mathrm{TC}$ & $37,87 \pm 0,71$ & $38,20 \pm 0,77$ & 0,006 \\
\hline $\mathrm{SpO}_{2} \%$ & $89,95 \pm 4,46$ & $91,29 \pm 2,90$ & 0,027 \\
\hline Лейкоцити, $10^{9} / л$ & $9,53 \pm 5,9$ & $7,79 \pm 3,94$ & 0,032 \\
\hline Глюкоза, ммоль/л & $7,93 \pm 4,79$ & $5,45 \pm 2,35$ & 0,000 \\
\hline Креатинін, мкмоль/л & $138,39 \pm 110,66$ & $98,01 \pm 21,25$ & 0,003 \\
\hline
\end{tabular}

Підвищення температури, як складова інфекційного процесу при COVID-19 пневмонії, у паці$\epsilon$ нтів з ХСН була нижчою $(p=0,006)$. В той же час, у них відзначався вищий рівень лейкоцитозу $(p=0,032)$, гіперглікемії ( $p<0,0001)$ та підвищеного креатиніну ( $p=0,003)$. Саме запальна відповідь, гіперглікемія, яка може бути відображенням стресової реакції та формування кардіоренального синдрому, можуть мати обтяжуючий вплив на $\mathrm{CH}$.

У пацієнтів з ХСН частіше траплялися кардіальні ускладнення, пов'язані з розвитком нестабільної стенокардії ( $p<0,001)$, інфаркту міокарда $(p=0,0094)$ та порушенням ритму і провідності $(p<0,001)$. У них була вища частота гострих тромбозів $(p=0,0181)$, тромбоемболії легеневої артерії (ТЕЛА) ( $<<0,001)$. Слід відзначити і вищу частоту кровотеч, які виникали під час COVID-19 і, можливо, були пов'язані з попереднім прийомом антитромботичної терапії. Що стосується гострих ускладнень зі сторони органів дихання, в тому числі гострого респіраторного дистрес-синдрому (ГРДС), - відмінностей в обох групах виявлено не було (табл. 2).

Госпітальна смертність у хворих на ХСН була також суттєво вищою, порівняно з пацієнтами без ХСН, і складала 27,8 \% проти 10,1 \% (р<0,001). Помирало 21,4 \% хворих з 1 та 2А стадією ХСН та 
Огляди літератури, оригінальні дослідження, погляд на проблему, випадок з практики, короткі повідомлення Таблиця 2. Гострі стани у пацієнтів з коронавірусною хворобою в поєднанні з ХСН (1 група) та без (2 група)

\begin{tabular}{|c|c|c|c|c|c|}
\hline \multirow{2}{*}{ Показники } & \multicolumn{2}{|c|}{1 група } & \multicolumn{2}{|c|}{2 група } & \multirow{2}{*}{$P$} \\
\hline & $\mathrm{n}=180$ & $\%$ & $n=209$ & $\%$ & \\
\hline Нестабільна стенокардія & 10 & 5,6 & 0 & 0 & 0,0005 \\
\hline Інфаркт міокарда & 10 & 5,6 & 2 & 1,0 & 0,0094 \\
\hline Порушення ритму і проведення & 32 & 17,8 & 2 & 1,0 & 0,000 \\
\hline Транзиторна ішемічна атака & 1 & 0,6 & 0 & 0 & 0,7232 \\
\hline ГПМК за тромбоішемічним типом & 8 & 4,4 & 22 & 10,5 & 0,4648 \\
\hline Крововилив у мозок & 0 & 0 & 6 & 2,9 & 0,0213 \\
\hline Гостра лівошлуночкова недостатність & 2 & 1,1 & 1 & 0,5 & 0,5018 \\
\hline Гострий тромбоз & 9 & 5 & 2 & 1,0 & 0,0181 \\
\hline Пневмоторакс & 3 & 1,7 & 3 & 1,4 & 0,8106 \\
\hline ТЕЛА & 37 & 20,6 & 19 & 9,1 & 0,0013 \\
\hline ГРДС & 35 & 19,4 & 28 & 13,4 & 0,1091 \\
\hline Шлунково-кишкові кровотечі & 13 & 7,2 & 6 & 2,9 & 0,0499 \\
\hline Псевдомембранозний коліт & 6 & 3,3 & 2 & 1,0 & 0,1117 \\
\hline Вперше діагностований діабет & 3 & 1,7 & 0 & 0 & 0,584 \\
\hline
\end{tabular}

вдвічі більше - 54,3 \% пацієнтів з ХСН 2Б та 3 стадії. Таким чином, можна припустити обтяжливий вплив коронавірусної хвороби на перебіг ХCH, який проявляється дестабілізацією серцево-судинних проявів хвороби, підвищенням тромбогенного потенціалу, що призводить до високої госпітальної летальності.

Висновок. Коронавірусна хвороба обтяжує перебіг ХСН. До факторів, що обтяжують хворобу, можна віднести: лейкоцитоз, гіперглікемію, яка може бути відображенням стресової реакції та креатиніну, з формуванням кардіоренального синдрому. Перебіг пневмонії COVID-19 проявляється дестабілізацією серцево-судинних проявів, підвищення тромбогенного потенціалу, що при- зводить до високої госпітальної летальності.

Перспективи подальших досліджень. Подальше вивчення та розкриття механізмів дестабілізації серцево-судинних проявів при коронавірусній хворобі $€$ надзвичайно важливим та актуальним. Зміни імунної реактивності, особливості цитокінового профілю у хворих на ХСН, роль стресових чинників, гіперглікемії потребують детальнішого вивчення. Перспективним, з нашого погляду, виглядає дослідження кардіоренальних механізмів, задіяних у перебігу коронавірусної хвороби. Розуміння патогенезу двосторонньої взаємодії між COVID-19 та CH, встановлення предикторів тяжкості може призвести до оптимального лікування і вплинути на прогноз стану пацієнта.

\section{ЛІТЕРАТУРА}

1. Association of influenza-like illness activity with hospitalizations for heart failure: the atherosclerosis risk in communities study / S. Kytömaa, S. Hegde, B. Claggett [et al.] // JAMA Cardiol. - 2019. - Vol. 4 (4). - P. 363-369.

2. Cardiovascular disease and COVID-19: insight from cases with heart failure / Y. Yi, Y. Xu, H. Jiang [et al.] // Front. Cardiovasc. Med. - 2021. - Vol. 8. - P. 629958.

3. Prognostic impact of prior heart failure in patients hospitalized with COVID-19 / S. Lee, A. Gupta, M. Cagliostro

\section{REFERENCES}

1. Kytömaa, S., Hegde, S., Claggett, B., Udell, J.A., Rosamond, W., Temte, J., ..., \& Vardeny, O. (2019). Association of influenza-like illness activity with hospitalizations for heart failure: the atherosclerosis risk in communities study. JAMA Cardiology, 4 (4), 363-369. DOI: https://doi. org/10.1001/jamacardio.2019.0549.

[et al.] // J. Am. Coll. Cardiol., - 2020. - Vol. 76 (20). P. 2334-2348.

4. Heart failure and COVID-19 / F. Bader, Y. Manla, B. Atallah [et al.] // Heart Fail. Rev. - 2021. - Vol. 26 (1). P. 1-10.

5. Clinical course and risk factors for mortality of adult inpatients with COVID-19 in Wuhan, China: a retrospective cohort study / F. Zhou, T. Yu, R. Du [et al.] // Lancet. - 2020. - Vol. 395 (10229). - P. 1054-1062.

2. Yi, Y., Xu, Y., Jiang, H., \& Wang, J. (2021). Cardiovascular disease and COVID-19: insight from cases with heart failure. Front. Cardiovasc. Med., 8, 629958. DOI: https://doi.org/10.3389/fcvm.2021.629958.

3. Alvarez-Garcia, J., Lee, S., Gupta, A., Cagliostro, M., Joshi, A.A., Rivas-Lasarte, M., ..., \& Lala, A. (2020). Prognostic 
Огляди літератури, оригінальні дослідження, погляд на проблему, випадок з практики, короткі повідомлення impact of prior heart failure in patients hospitalized with COVID-19. J. Am. Coll. Cardiol., 76 (20), 2334-2348. https:// doi.org/10.1016/j.jacc.2020.09.549

4. Bader, F., Manla, Y., Atallah, B., \& Starling, R.C. (2021). Heart failure and COVID-19. Heart Failure Rev., 26 (1), 1-10. https://doi.org/10.1007/s10741-020-10008-2

5. Zhou, F., Yu, T., Du, R., Fan, G., Liu, Y., Liu, Z., ..., \& Cao, B. (2020). Clinical course and risk factors for mortality of adult inpatients with COVID-19 in Wuhan, China: a retrospective cohort study. Lancet (London, England), 395 (10229), 1054-1062. DOI: https://doi.org/10.1016/S01406736(20)30566-3.

\section{FEATURES OF THE COURSE OF CORONAVIRUS DISEASE IN HEART FAILURE ๑O. O. Samchuk', O. S. Kapustynska², Ye. Ya. Sklyarov² \\ ${ }^{1}$ Municipal non-profit enterprise "Lviv Clinical Emergency Hospital" ${ }^{2}$ Danylo Halytsky Lviv National Medical University}

SUMMARY. Coronavirus disease 2019 (COVID-19) is a more aggressive infection in which the risk of exacerbations increases significantly. Recent data suggest that a large proportion of deaths from COVID-19 can be attributed to cardiovascular disease, including HF [2]. HF is associated with almost a double risk of in-hospital mortality and treatment in the intensive care unit and more than threefold risk of mechanical ventilation.

The aim - to evaluate the features of the course of COVID-19 in patients with HF based on retrospective analysis.

Material and Methods. The clinical and laboratory features of the course of COVID-19 in patients with chronic HF were investigated, as well as complications, treatment results (discharge / death) based on the analysis of medical cards of 389 patients treated at the Municipal Non-Profit Enterprise "Lviv Clinical Emergency Hospital" in January and February 2021.

Results. Chronic HF was detected in $46.3 \%$ of patients with COVID-19. These patients were more likely to have shortness of breath ( $88.2 \%$ vs. $71.4 \%$ in patients without chronic HF, $p=0.074)$, lower saturation level $(p=0.027)$, higher levels of leukocytosis $(p=0.032)$, hyperglycemia $(p<0.0001)$ and creatinine $(p=0.003)$. Cardiac complications associated with the development of unstable angina $(p<0.001)$, myocardial infarction $(p=0.0094)$, arrhythmia and conduction disorders $(p<0.001)$ were more common in the study group of patients. They had a higher incidence of acute thrombosis $(p=0.0181)$, pulmonary embolism $(p<0.001)$ and hospital mortality $27.8 \%$ vs. $10.1 \%(p<0.001)$.

Conclusions. Coronavirus disease aggravates the course of chronic HF and manifests itself in the destabilization of the cardiovascular manifestations of the disease, an increase in thrombogenic potential, which leads to high hospital mortality.

KEY WORDS: COVID-19; heart failure. 